\title{
Magnetic and Gravity Constraints on Forearc Upper Crustal Structure and Composition, Offshore Northeast Japan
}

\author{
Carol FINN \\ U.S. Geological Survey, MS 964, Denver Federal Center, Denver, CO 80225, U.S.A.
}

(Received August 12, 1992; Revised March 22, 1993; Accepted March 28, 1993)

\begin{abstract}
Marine magnetic and gravity data from the northeast Japan forearc offer insight to the subsurface structure, density and magnetization from which geologic interpretations and tectonic reconstructions can be made. Positive marine magnetic anomalies, on-land geology, drill hole data, and 2-1/2dimensional models reveal that Kitakami plutons and possibly their associated volcanic rocks constitute part of the modern forearc basement and lie $100-150 \mathrm{~km}$ further east than previously thought. A method to create magnetization and density contrast maps was employed to produce a three-dimensional picture of the forearc basement rock properties averaged over a 14-km thickness. Comparisons of the magnetization map with drill hole information suggest that Cretaceous andesites may contribute to the observed positive aeromagnetic anomalies and therefore, may be more magnetic than the sparse on-land rock property measurements suggest. The lower magnetization values for the area south of $40^{\circ} \mathrm{N}$ latitude than for the area to the north may indicate that the andesites are not present in the south and erosion was deeper there. The gravity data primarily reflect variations of density within marine sedimentary rocks and crustal thickness.
\end{abstract}

\section{Introduction}

Marine magnetic and gravity data over convergent-plate margins are powerful tools to delineate subsurface structure and magnetization and density distributions. Early marine gravity surveys by Vening Meinesz (1934) found large-amplitude negative free-air gravity anomalies over trenches and positive anomalies over island arcs and forearcs. Bathymetry, and the density contrast of water, low density sedimentary rocks with adjacent dense sedimentary rocks and oceanic crust cause the negative trench anomaly. Controversy exists over the sources of the positive anomalies. Gravity models (Grow, 1973; Grow and Bowin, 1975; Kogan, 1975; Segawa and Tomoda, 1976) have been interpreted to show that much of the convergent margin gravity signature can be explained by the density contrast between the subducting plate and the surrounding asthenosphere and by contrasts due to phase-change induced density increases within the subducting plate. Others (Watts and Talwani, 1975; Couch and Woodcock, 1981; Couch and Riddihough, 1989; Fukao et al., 1989; Finn, 1990) suggest that density contrasts in the upper $50 \mathrm{~km}$ are the primary causes of the observed gravity anomalies.

Marine and aeromagnetic data have also delineated forearc crustal composition. Magnetic highs in forearc regions reveal accreted oceanic terranes in Washington (Finn, 1990), Mexico (Couch and Woodcock, 1981), and the Philippines (Hayes and Lewis, 1984) and a Cretaceous batholith in northeast Japan (Finn, in press). Magnetic lows reveal forearc and accretionary prism sedimentary rocks in the Alaska forearc (Grow, 1973).

Northeast Japan has a very wide areal distribution of publicly available marine gravity and magnetic data, so large that the data can be used for three-dimensional interpretations instead of the usual two dimensions. In this paper, I apply a 3-dimensional method for magnetization and density mapping of the northeast Japan forearc and present geologic interpretations. 


\section{Geology}

Japan has been a convergent margin for much of its history since the Mesozoic. The modern plate geometry of the region (Fig. 1) has developed since the late Miocene (Honza, 1980). The geology offshore of northeast Japan is not well known. Interpretations of drilling (von Huene et al., 1982; Japan Association of Natural Gas, 1986), gravity data (Nishimura and Murakami, 1977; Nishimura et al., 1984), and seismic refraction and reflection data (Honza et al., 1978; Asano et al., 1979; von Huene et al., 1982; Suyehiro et al., 1990) suggest that the near-trench Pacific forearc consists of Neogene and Quaternary forearc basin sedimentary rocks floored by a basement of Cretaceous sedimentary rocks.

Clues to the composition of the near-shore forearc basement can be found in the Kitakami geologic province of northeast Tohoku as well as in central Hokkaido (Figs. 2 and 3) (Yamada et al., 1982). The basement rocks of the Kitakami Province primarily consist of Paleozoic, Triassic, and Jurassic marine and

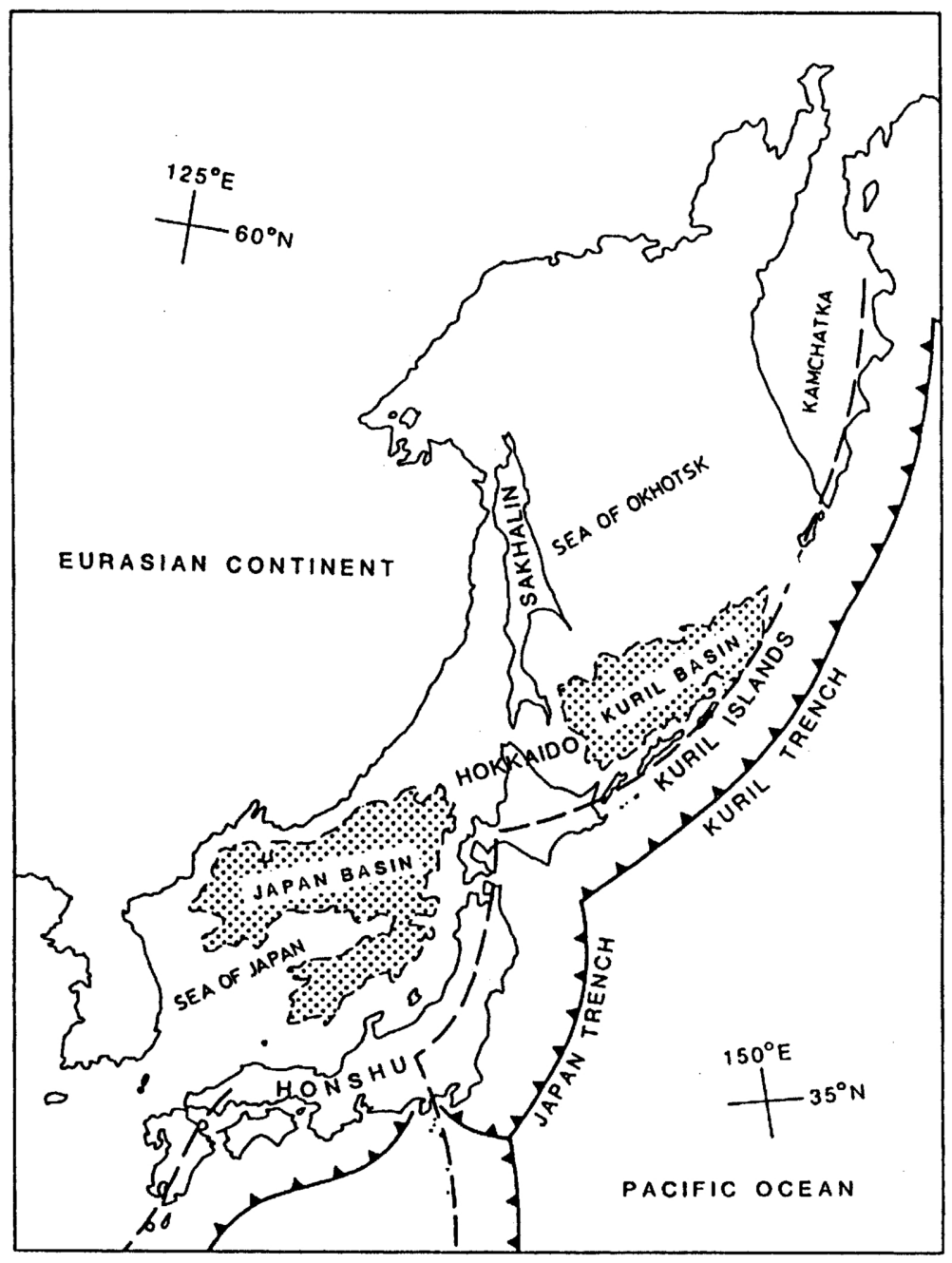

Fig. 1. Plate tectonic setting of Japan (after Maeda (1986)). 
continental sedimentary rocks. Most of these rocks were originally part of the Asian continental margin although some were accreted in the Mesozoic (Saito and Hashimoto, 1982). In the Early Cretaceous, subduction of the Izanagi plate (Taira et al., 1983) produced the Kitakami plutons and associated volcanic rocks (Figs. 2 and 3) (Kanisawa et al., 1984). Exposed Kitakami plutons and basement sedimentary rocks

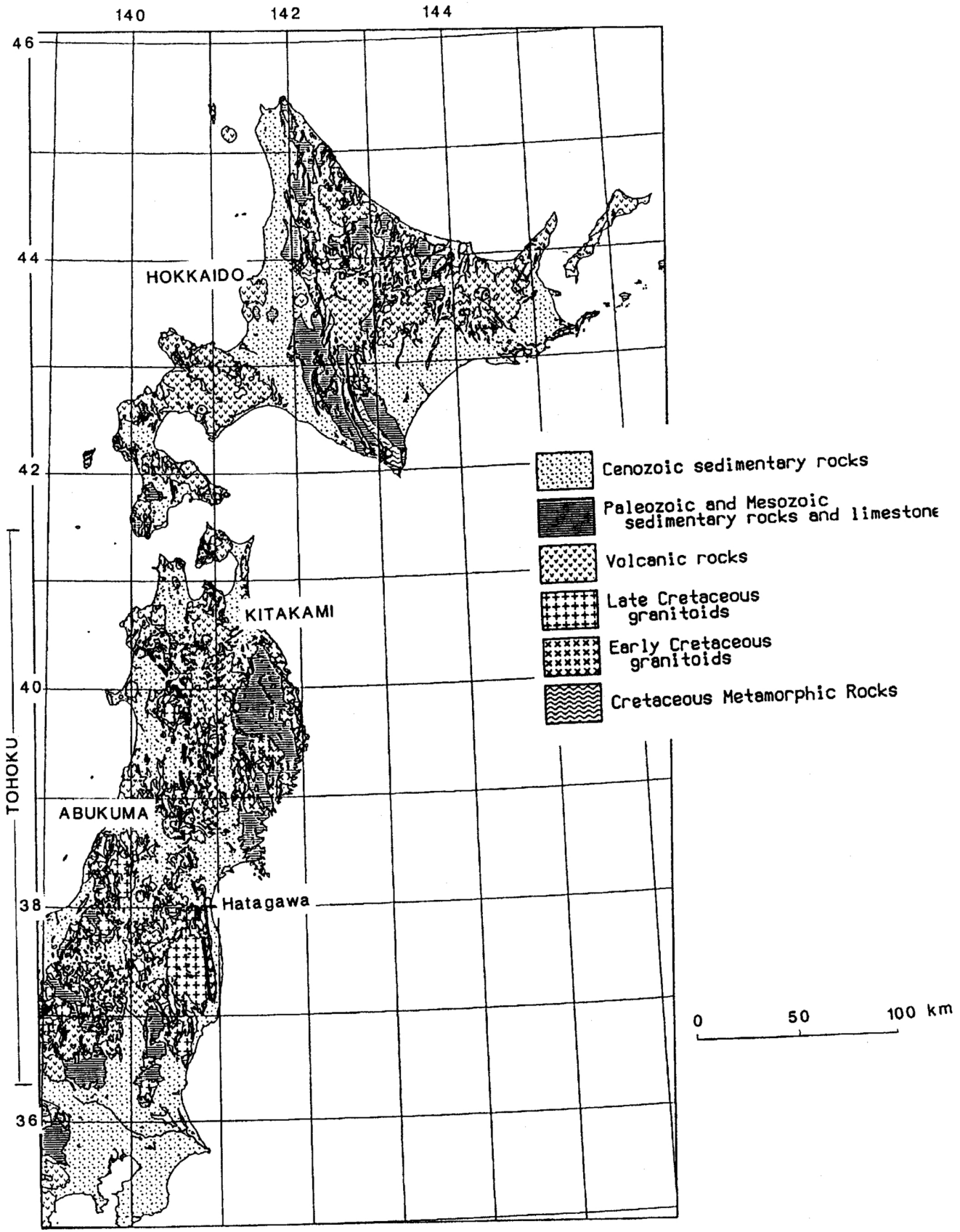

Fig. 2. Generalized geologic map of northeast Japan (after Yamada et al. (1990)). 


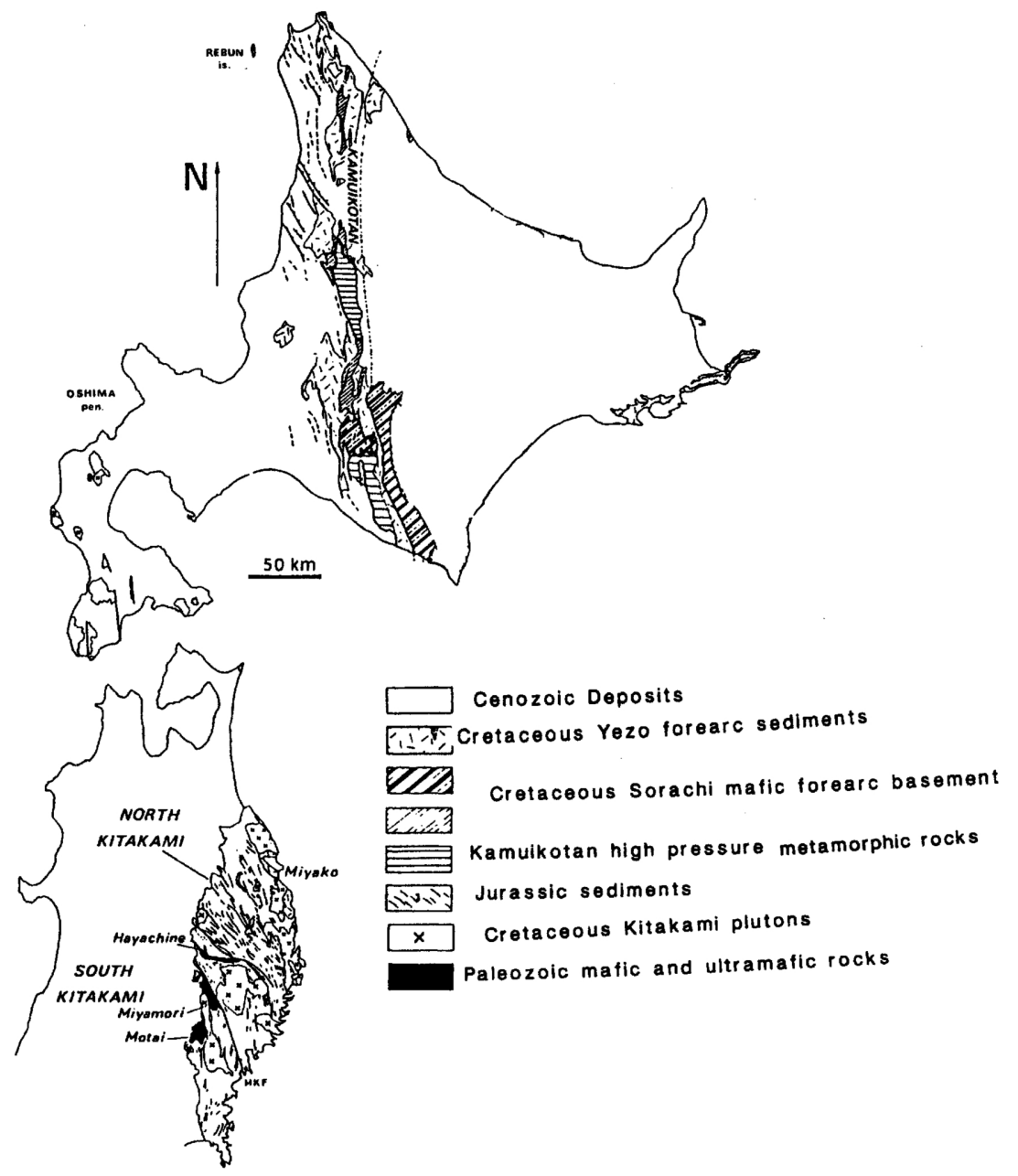

Fig. 3. Detailed geologic map of northern Honshu and Hokkaido (after Jolivet et al. (1988)).

extend from southeastern Tohoku, north to the Oshima peninsula in southwestern Hokkaido (Figs. 2 and 3). Associated with the Kitakami plutonic and volcanic rocks are Cretaceous forearc basin sedimentary rocks (the Yezo Formation) and mafic oceanic basement (the Sorachi Formation) and accretionary prism rocks, also part of the Sorachi Formation, exposed in Hokkaido (Fig. 3). In the early Cretaceous, metamorphosed melange, now the blue-schist and serpentines of the Kamuikotan Formation, intruded the central forearc (Yezo Formation) (Niida and Kito, 1986).

In the Miocene, the Japan Sea opened, rifting the Japanese Islands from Asia and causing counterclockwise rotation of Tohoku (Otofuji et al., 1985). Modern subduction along the Japan trench may have started in the Miocene (Honza et al., 1978). Opening of the Kuril Basin (Fig. 1) in the Neogene, caused right-lateral strike-slip faulting and uplift in central Hokkaido, resulting in the formation of anticlinal cores of the Kamuikotan metamorphic rocks with Cretaceous forearc (Yezo) and accretionary prism rocks (Sorachi) outboard (Kimura et al., 1983). These rocks may continue to the south and compose part of the Cretaceous basement of the modern Pacific forearc region (Niitsuma et al., 1988), but this is not known.

The Kitakami plutons and serpentines of the Kamuikotan metamorphic belt (Fig. 3) produce positive aeromagnetic anomalies; I used the aeromagnetic data to locate these rocks offshore. 


\section{Aeromagnetic and Gravity Data}

Onshore in the Kitakami Province, 2-20 km diameter intrusions have low remanence $(Q$ values are generally less than 0.2) (Murata et al., 1991) but relatively high magnetic susceptibilities, with averages as high as $55 \times 10^{-3}$ SI units (Kanaya, 1974; Ishihara, 1978, 1979) and most are associated with positive aeromagnetic anomalies with amplitudes of 300 to $900 \mathrm{nT}$ peak to trough (Fig. 4). Magnetotelluric (MT) data (Ogawa, 1992) indicate that the plutons are about $3 \mathrm{~km}$ thick. The associated volcanic rocks, although not extensively sampled, have low susceptibilities (Okuma, personal communication, 1991) and low remanence (intensities less than $0.1 \mathrm{~A} / \mathrm{m}$, Tosha, written communication, 1991). However, some exposures of the volcanic rocks are associated with aeromagnetic highs, suggesting either that the volcanic rocks can be magnetic or that they are underlain by the plutons. More rock magnetic property measurements and modeling of the aeromagnetic data are needed to determine which alternative is correct.

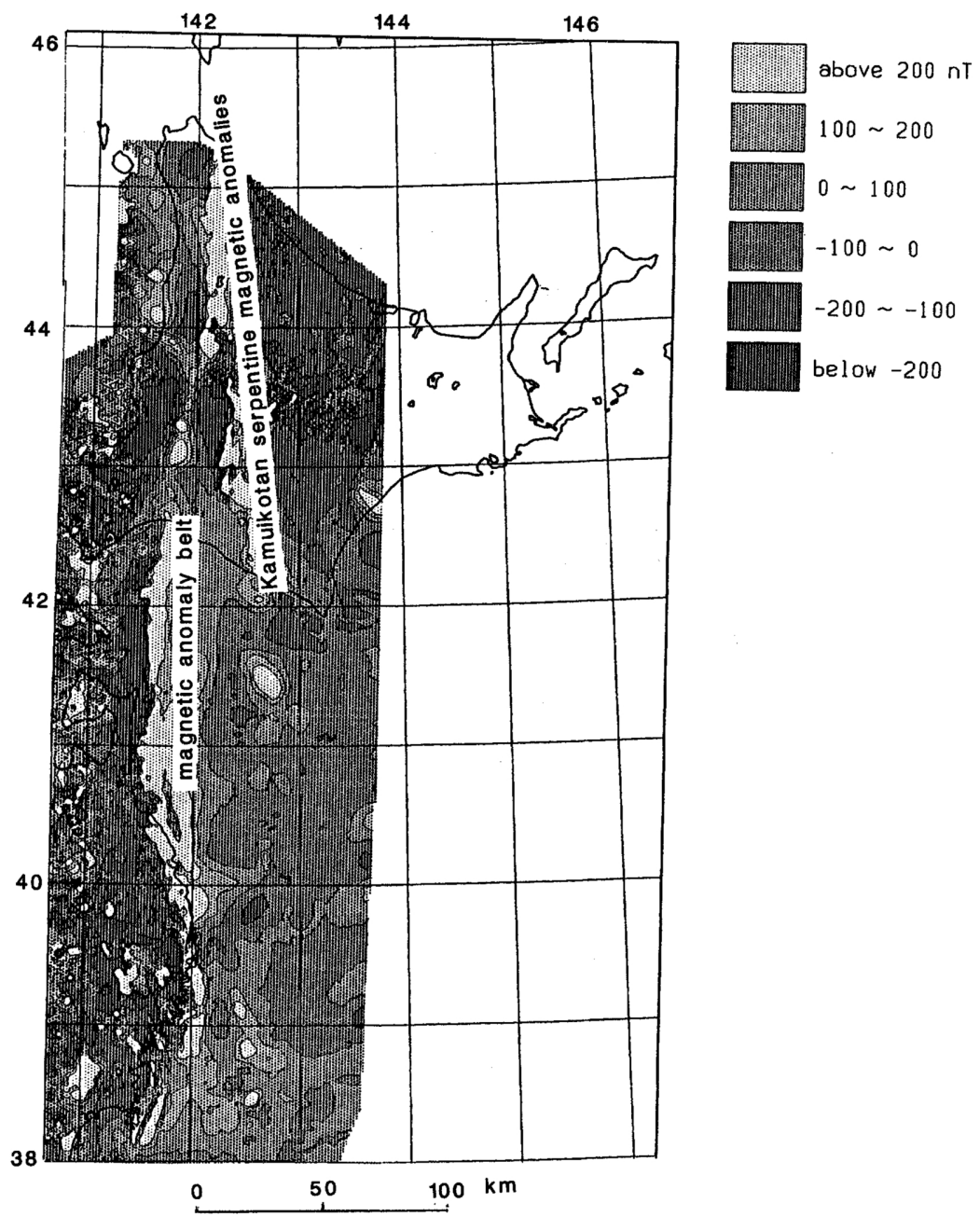

Fig. 4. Gray-scale aeromagnetic map (flown at a $4500 \mathrm{ft}$ elevation, from the New Energy Development Organization, Makino et al. (1992)). 
At the eastern coast north of $39^{\circ} \mathrm{N}$ and offshore is a north-trending $50-\mathrm{km}$ wide belt of magnetic highs with amplitudes of 300 to $900 \mathrm{nT}$ peak to trough (Figs. 4 and 5). The association of positive aeromagnetic anomalies on land with exposed rocks (compare Figs. 2 and 4) and offshore drilling (Fig. 5) reveals that the magnetic belt is primarily due to the Kitakami plutons and possibly the associated volcanic rocks (Finn, 1991). The drilling results will be discussed later. The MT data (Ogawa, 1992) show that at the coast, the plutons causing the magnetic anomaly belt are about $15 \mathrm{~km}$ thick. The positive anomaly belt was originally interpreted to be due to a Jurassic or early Cretaceous mafic dike or volcanic rocks (Ogawa and Suyama, 1975; Segawa and Oshima, 1975; Segawa and Furuta, 1978; Makino et al., 1992).

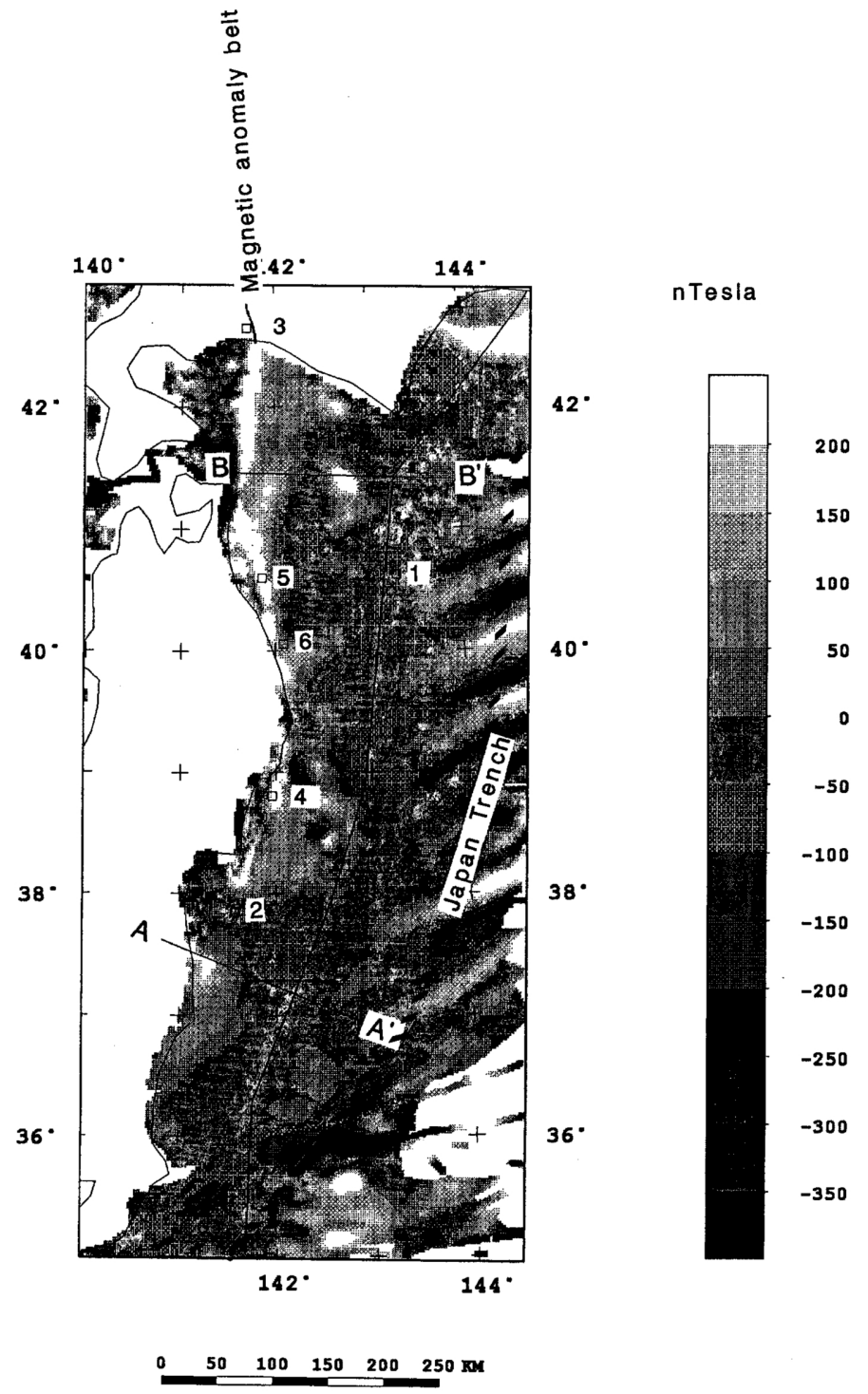

Fig. 5. Gray-shade marine magnetic map. Squares with numbers mark the location of drill holes. Lines A-A' and B-B' show locations of modeled magnetic profiles. The Japan trench is indicated by the dashed line. The north-trending line divides the near-shore magnetic data used from magnetization mapping (Fig. 10) from the magnetic stripe data. 
East of the magnetic anomaly belt (Figs. 4 and 5), north of $41^{\circ} \mathrm{N}$, are several small, high-amplitude positive magnetic anomalies that lie directly south of large-amplitude positive magnetic anomalies in Hokkaido associated with the Kamuikotan serpentines (compare Figs. 3 and 4). The offshore anomalies may be associated with the serpentines or the Kitakami plutons.

The positive and negative stripes on the eastern side of the marine magnetic map (Fig. 5) are caused by normally and reversely magnetized oceanic crust of the Pacific plate. They attenuate to the west due to the increasing depth of the plate as it subducts (Makino and Okubo, 1988; Okubo et al., 1991).

Associated with the Japan arc-trench system is the characteristic free-air gravity signature of active subduction zones, that of a low over the trench and a high arcward (west) of it (Fig. 6). The signature is caused mainly by bathymetry and density contrasts within the uppermost $50 \mathrm{~km}$ (Finn, 1988).

In general, the gravity and magnetic data do not have the same features. The near shore gravity highs may partially correspond to the Kitakami magnetic plutons, but the rest of the map shows bathymetry and variations of density within the sedimentary rocks in the forearc and trench and crustal thickness (Finn, in press). Producing the gravity low over the Hidaka Basin (Fig. 6) is the negative density contrast between

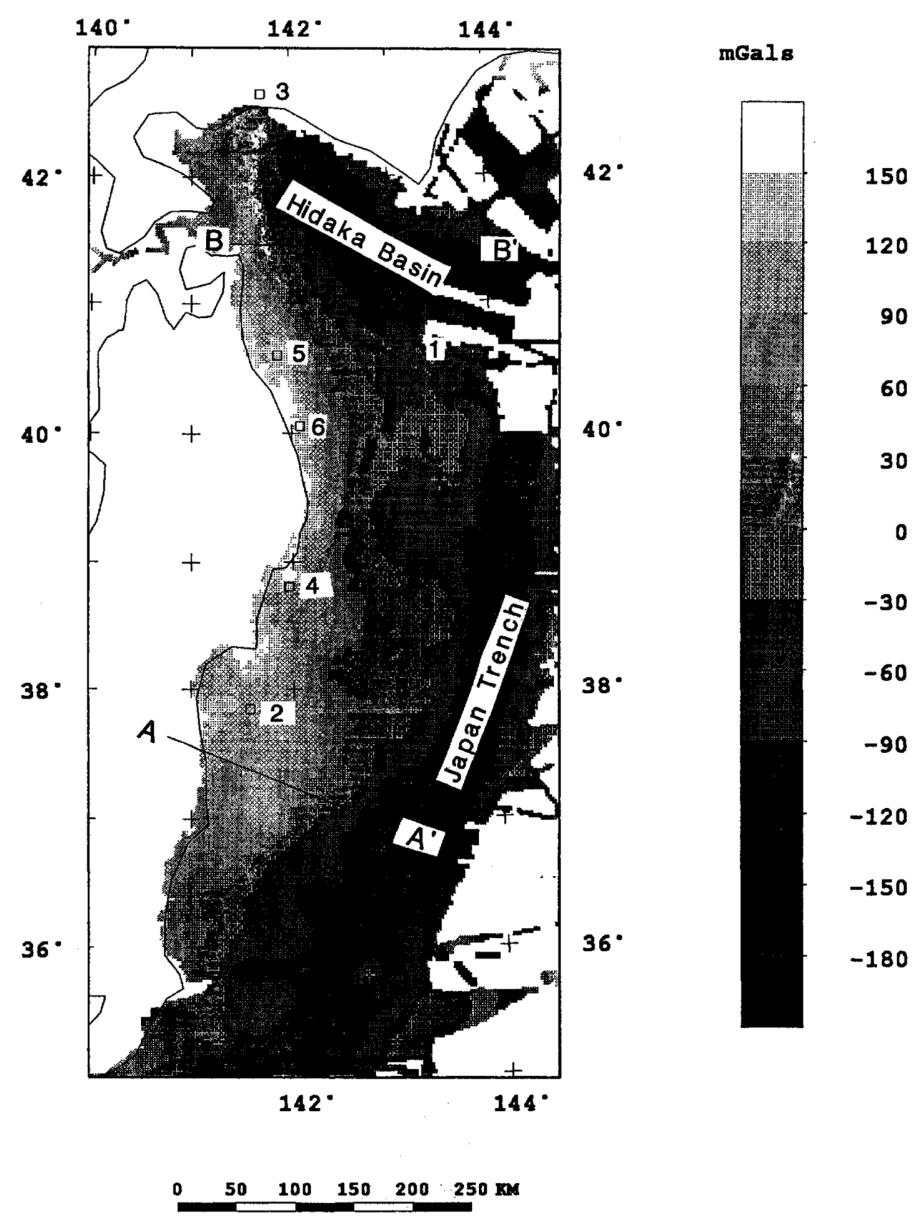

Fig. 6. Gray-shade marine free-air gravity map. Squares with numbers mark the location of drill holes. Lines A-A' and B-B' show locations of modeled gravity profiles. The Japan trench is indicated by the dashed line. 
relatively low density Quaternary sedimentary rocks within the basin and the adjacent Miocene sedimentary rocks (Committee for Co-Ordination of Joint Prospecting for Mineral Resources in Asian Offshore Areas (CCOP), 1991).

\section{Magnetic and Gravity Modeling}

The qualitative interpretation presented above gives information on the lateral extent of the sources of observed gravity and magnetic anomalies. In order to estimate the geometries, densities, and magnetizations that produce the observed gravity and magnetic anomalies, modeling is usually necessary. I used 2 methods, a 3-d magnetization mapping procedure described later and a 2-1/2-dimensional, forward-and-inverse gravity and magnetic profile modeling program (Webring, 1985).

\subsection{Two-dimensional modeling}

Two-1/2-dimensional magnetic and gravity models (Figs. 7 and 8 ) from the southern (A-A', Figs. 4,5 and 6) and northern (B-B', Figs. 5 and 6) parts of the study area, although not well constrained, offer insight into the forearc crustal structure. The Kitakami plutons seem to cause the observed magnetic highs but are not associated with offshore gravity anomalies.

In the models the total magnetizations of bodies are assumed to be in the present Earth's field, with direction of inclination $50^{\circ}$, declination $6.5^{\circ}$, and intensity of 46,000 nT (Geological Survey Institute, 1983). The geologically reasonable sources of magnetic anomalies in the region are Kitakami plutons, serpentine, and volcanic rocks. The assumption of the induced component as the primary contributor to the total magnetization is reasonable for the Kitakami plutons for several reasons: 1) Remanent intensities are low relative to the susceptibilities; the Koenigsberger ratios measured for plutons in the northern part of the Kitakami province are generally less than 0.2 (Murata et al., 1991).2) Analysis of a limited number of samples from Kitakami plutons with both remanent and susceptibility measurements (Murata et al., 1991) shows that remanent vectors for most plutons are within $25^{\circ}$ of the present Earth's field direction. Vectors within about $25^{\circ}$ of the present Earth's field direction can be considered effectively collinear with it (Bath, 1968). 3) Calculated magnetizations from modeling of aeromagnetic data over Kitakami plutons whose thicknesses were constrained with MT data, were within $85 \%$ of the average of measured values (Ogawa, 1992). Therefore, susceptibility, rather than remanence, is the primary contributor to the total magnetization sensed by the aeromagnetic data.

In serpentine, the induced component is 3 times greater than that of remanence (DuBois, 1963). In volcanic rocks, remanent is usually much stronger than induced magnetization. For the volcanic rocks of interest, the Cretaceous Kitakami rocks, however, measured remanent intensities are usually 10 to 100 times less than susceptibility (Tosha, written communication, 1991; Okuma, written communication, 1992); induced magnetization contributes much more than remanence to the total magnetization.

Initial density and susceptibility values were based on rock property measurements (Kanaya, 1974; Tanaka and Kanaya, 1986, 1987). A magnetization of 0 and a density of $1030 \mathrm{~kg} / \mathrm{m}^{3}$ were assigned to the sea water. All other density and magnetization values were allowed to vary within geologically reasonable ranges in the program.

The model along profile $\mathrm{A}-\mathrm{A}^{\prime}$ in the southern offshore area (Fig. 7) is described in detail in Finn (in press). Seismic refraction data from offshore (Segawa and Tomoda, 1976; von Huene et al., 1982) and onshore (Iwasaki et al., 1991) constrain the top of the lower continental crust and mantle and position of the subducting plate. The following discussion will focus on the offshore upper crustal structure based on the modeling results.

Kitakami plutons exposed between the Hatagawa and Futaba Faults have high susceptibilities and are associated with aeromagnetic highs (Fig. 7) (Kubo and Yamamoto, 1990; Finn, in press). East of the Futaba Fault, onshore drilling (Abe and Ishihara, 1985) and positive aeromagnetic anomalies (Finn, in press) indicate that the Kitakami plutons lie beneath the surface. MT data (Ogawa, written communication, 1991) determine a $15 \mathrm{~km}$ thickness for the Kitakami plutons onshore east of the Hatagawa Fracture 
zone (about $37^{\circ} 30^{\prime} \mathrm{N}$ latitude, Fig. 2). The gravity and magnetic data require that the top of the Kitakami pluton deepens from depths below sea level of about $300 \mathrm{~m}$ onshore to $5000 \mathrm{~m}$ offshore (Fig. 7). The sharp deepening of the pluton near the coast may represent a fault. The calculated density of $2680 \mathrm{~kg} / \mathrm{m}^{3}$ and magnetization of $3.01 \mathrm{~A} / \mathrm{m}$ for the pluton is compatible with measured susceptibility values for exposed Kitakami plutons (Kanaya, 1974; Kubo et al., 1990).

Seismic refraction velocities of 4.3 to $4.7 \mathrm{~km} / \mathrm{s}$ (Suyehiro et al., 1984) for the body with assigned density $2600 \mathrm{~kg} / \mathrm{m}^{3}$ (Fig. 7) are much lower than the 6 to $6.5 \mathrm{~km} / \mathrm{s}$ (Iwasaki et al., 1991) velocities measured for exposed Kitakami plutons. The most geologically reasonable source for the $2600 \mathrm{~kg} / \mathrm{m}^{3}$ density body is sedimentary rock. The high density of these sedimentary rocks suggests that they are moreconsolidated and older, possibly Tertiary, sedimentary rocks than the $2100 \mathrm{~kg} / \mathrm{m}^{3}$ density Quaternary marine sedimentary rocks (Fig. 7). The refraction data also constrain the top of the Kitakami pluton to be below the 4.3 to $4.7 \mathrm{~km} / \mathrm{s}\left(2600 \mathrm{~kg} / \mathrm{m}^{3}\right.$, Fig. 7) layer.

The $2740 \mathrm{~kg} / \mathrm{m}^{3}$ density calculated from the model for the body east of the pluton (Fig. 7) is compatible with the measured seismic refraction velocities of about 5.5 to $5.7 \mathrm{~km} / \mathrm{s}$ (Suyehiro et al., 1984, 1990). The susceptibility for this body calculated from the model is $0 \mathrm{~A} / \mathrm{m}$. The only geologically reasonable rock type for this body is sedimentary, not crystalline. The positive gravity anomaly on the eastern end of the profile requires that these dense sedimentary rocks shallow from about $6 \mathrm{~km}$ depth to $1.3 \mathrm{~km}$ (at distance 85, Fig. 7). In this same area, seismic reflection data (Sakurai et al., 1981) show an anticline in a sedimentary section. The position of these rocks relative to the Kitakami plutons suggests that they belong to the early Cretaceous forearc. Seismic velocities measured in Hokkaido for the Yezo Formation are $4.7-5 \mathrm{~km} / \mathrm{s}$ underlain by a $5.8 \mathrm{~km} / \mathrm{s}$ layer (Fujii and Moriya, 1983) that may belong to the Sorachi Formation. It is possible that Sorachi rocks compose the $2740 \mathrm{~kg} / \mathrm{m}^{3}$ density layer, but this is speculative.

Further to the east, are rocks with a calculated density of $2540 \mathrm{~kg} / \mathrm{m}^{3}$ and $0 \mathrm{~A} / \mathrm{m}$ magnetization, compatible with sedimentary rocks of undetermined age. The $50 \mathrm{nT}$ magnetic high at the eastern end of the profile (between 125 and $175 \mathrm{~km}$ ) is part of the stripes (Fig. 4) caused by normally magnetized oceanic crust in the subducting plate not included in the model.

Other gravity and magnetic profiles, B-B' (Figs. 5 and 6) located north of profile A-A' can be explained by two alternate models (Fig. 8). The magnetic profile has 2 positive anomalies, both of which can be explained by a Kitakami pluton greater than about $5 \mathrm{~km}$ deep (Fig. 8(a)). The calculated magnetization of $3.8 \mathrm{~A} / \mathrm{m}$ is higher than the average range of $1.5-3 \mathrm{~A} / \mathrm{m}$ for those measured onshore (Kanaya, 1974), suggesting that this model is not correct. It is also possible to model the two highs as separate plutons in which case the western pluton has a magnetization of about $2.4 \mathrm{~A} / \mathrm{m}$ and the eastern one has a magnetization of about $3.5 \mathrm{~A} / \mathrm{m}$. Another possibility is that early Cretaceous volcanic rocks with high magnetizations overlie the plutons. The gravity high on the western part of the profile is caused by the density contrast between the pluton and higher density rocks $\left(2740 \mathrm{~kg} / \mathrm{m}^{3}\right)$. The only geologically reasonable explanation for these high density rocks are old sedimentary rocks, perhaps the Kitakami preCretaceous basement rocks. The density of the pluton $\left(2710 \mathrm{~kg} / \mathrm{m}^{3}\right)$ is not sufficiently different from other adjacent sedimentary rocks $\left(2640 \mathrm{~kg} / \mathrm{m}^{3}\right)$ to cause a significant gravity anomaly.

An alternative source for the eastern-most positive magnetic anomaly is Kamuikotan serpentine with a magnetization of $13 \mathrm{~A} / \mathrm{m}$ (Fig. 8(b)). The 2-km thickness of the proposed serpentine body was constrained by MT data from Hokkaido (Ogawa, written communication, 1991) and extrapolated to the offshore area. In the alternative model (Fig. 8(b)), the Kitakami pluton has a magnetization of $2.74 \mathrm{~A} / \mathrm{m}$, more in line with measured values. However, the $13 \mathrm{~A} / \mathrm{m}$ magnetization is higher the $6-10 \mathrm{~A} / \mathrm{m}$ range modeled for exposed 2-km thick serpentines in Hokkaido, although it is reasonable for serpentine. Cretaceous sedimentary rocks probably compose bodies other than the pluton with densities greater than $2600 \mathrm{~kg} / \mathrm{m}^{3}$. Where the Kamuikotan serpentines are exposed in Hokkaido (Fig. 3), they form the core of an anticline with the Yezo and Sorachi Formations outboard. If a Kamuikotan serpentine is the source of the eastern magnetic high, then the 2620 and $2770 \mathrm{~kg} / \mathrm{m}^{3}$ layers (Fig. 8(b)) would most likely represent sedimentary rocks of the Yezo and mafic rocks of the Sorachi Formations, respectively. 


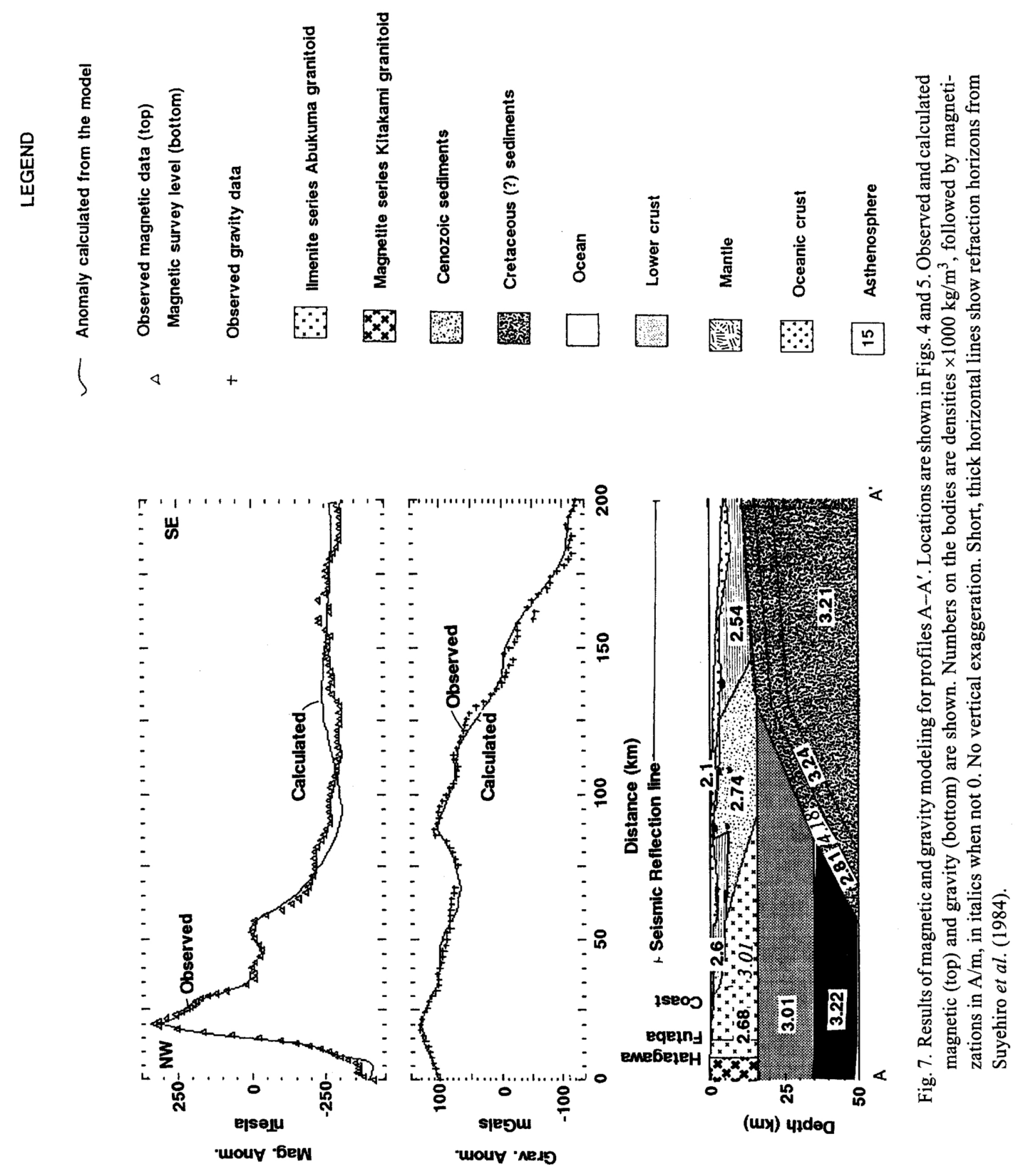



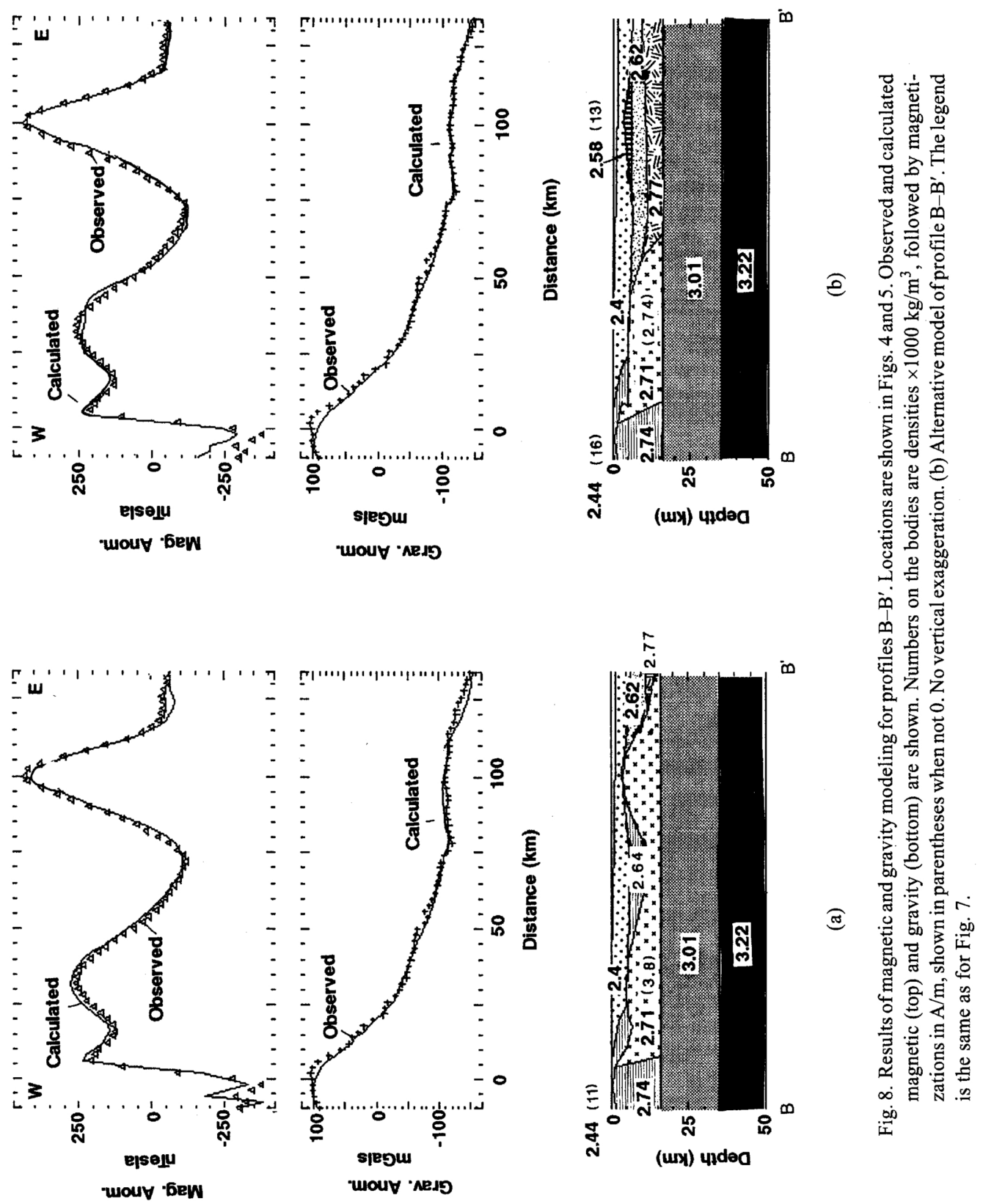


\subsection{Magnetization mapping}

A recently developed method called "terrace", can be used to produce crude two- or threedimensional physical property maps from magnetic and gravity data (Cordell and McCafferty, 1989). The method uses the sense of the data's local curvature to produce a field comprised of relatively uniform domains separated by abrupt boundaries unlike the smooth boundaries of potential field data but akin to a geologic map (Cordell and McCafferty, 1989). If the thickness of a domain is known, the field can be extended to a density or magnetization model. The resulting vertically-bounded magnetization blocks are usually distributed throughout a horizontal layer. I applied the terrace procedure to near-shore magnetic data to amplify differences in depth and/or magnetization of the Kitakami plutons that cause the majority of the observed positive anomalies (Finn, 1991, in press).

Only the magnetic data west of the north-trending line in Fig. 5 were input to the terrace program in order to isolate the near-shore positive anomalies of interest. These data were transformed to pseudogravity anomalies (Baranov, 1957) using frequency-domain filtering (Hildenbrand, 1983) to reduce noise and shift anomalies over their sources. The output from the terracing operator is a field with values in pseudo-mGals with the exact range of the input pseudo-gravity data. In order to convert the units of the pseudo-mGals map to units of magnetization, I calculated a forward model (Cordell et al., 1992) whose source had a flat top and bottom at depths of 1 and $15 \mathrm{~km}$, respectively. The top depth is probably a minimum as inferred from the offshore drill holes (Japan Association of Natural Gas, 1986). The depth to the bottom of the plutons was estimated from the onshore magnetotelluric data (Ogawa, 1992). All assumptions about the total magnetization made for the 2-1/2-dimensional models were applied to the 3 dimensional case, i.e., the total magnetization was modeled to be in the present Earth's field direction of inclination $=54$, declination $=6.5$ with an intensity of $46000 \mathrm{nT}$ (Geological Survey Institute, 1983). The calculated field was scaled in terms of a least squares fit by a constant to the observed data. The same scaling constant was applied to the terraced data to obtain the magnetization values shown in Fig. 9. Variations in magnetization in Fig. 9 may not be real and actually correspond to constant magnetization in a source with a variable depth to its surface. Because the exact shape of the top of sources is unknown, Fig. 9 will be considered a pseudo-magnetization map.

Areas with magnetizations greater than $0 \mathrm{~A} / \mathrm{m}$ primarily correspond to the Kitakami plutons and possibly their associated volcanic rocks. One exception is the area of 0 to $2 \mathrm{~A} / \mathrm{m}$ magnetization in the northwestern-most corner of the map (Fig. 9). Drilling shows this area to be underlain by Tertiary volcanic rocks (Japan Association of Natural Gas, 1986). Another exception may be the area north of $41^{\circ}$ and east of $142^{\circ} 30^{\prime}$ which may correspond to serpentine. The magnetization range of 2 to $4 \mathrm{~A} / \mathrm{m}$ is lower than modeled for serpentine, but is a function of the $15-\mathrm{km}$ thickness assigned to the magnetic sources. If the thickness were less, the magnetization would be higher.

The locations of magnetization values less than 0 may be places where the plutons are too deep to be detected, rather than indicate the presence of rocks with reversed or low magnetizations. The wide range of 0 to $8 \mathrm{~A} / \mathrm{m}$ in the positive magnetization values may reflect depth differences rather than lateral changes in magnetization.

Information from the drill holes can help to constrain which alternative is most reasonable. Where drill hole 4 (Japan Association of Natural Gas, 1986) encountered a Kitakami pluton with no associated volcanic rocks at a depth of $1.8 \mathrm{~km}$, the pseudo-magnetization map (Fig. 9) shows average values between 0 to $2 \mathrm{~A} / \mathrm{m}$. To the north, where magnetization values are greater than $4 \mathrm{~A} / \mathrm{m}$, drill holes 5 and 6 (von Huene et al., 1982) encountered Cretaceous andesites at depths of 3.2 and $3.8 \mathrm{~km}$, respectively, but no plutons and no other shallower magnetic rocks. Values greater than about $5 \mathrm{~A} / \mathrm{m}$ are higher than measured averages for plutons onshore. If the plutons underlie the andesites, they cannot be the sole source of the high magnetizations and that despite low measured magnetization values onshore (S. Okuma, personal communication, 1991), the andesites must be magnetic.

Drill hole 3 (Yufutsu Research Group of JAPEX Sapporo et al., 1992) encountered a Kitakami pluton at $5 \mathrm{~km}$ depth overlain by non-magnetic sedimentary rocks. It lies on the northwestern edge of a zone of 4 to $6 \mathrm{~A} / \mathrm{m}$ magnetization values. The pluton may shallow to the southeast or be covered by andesites there. 


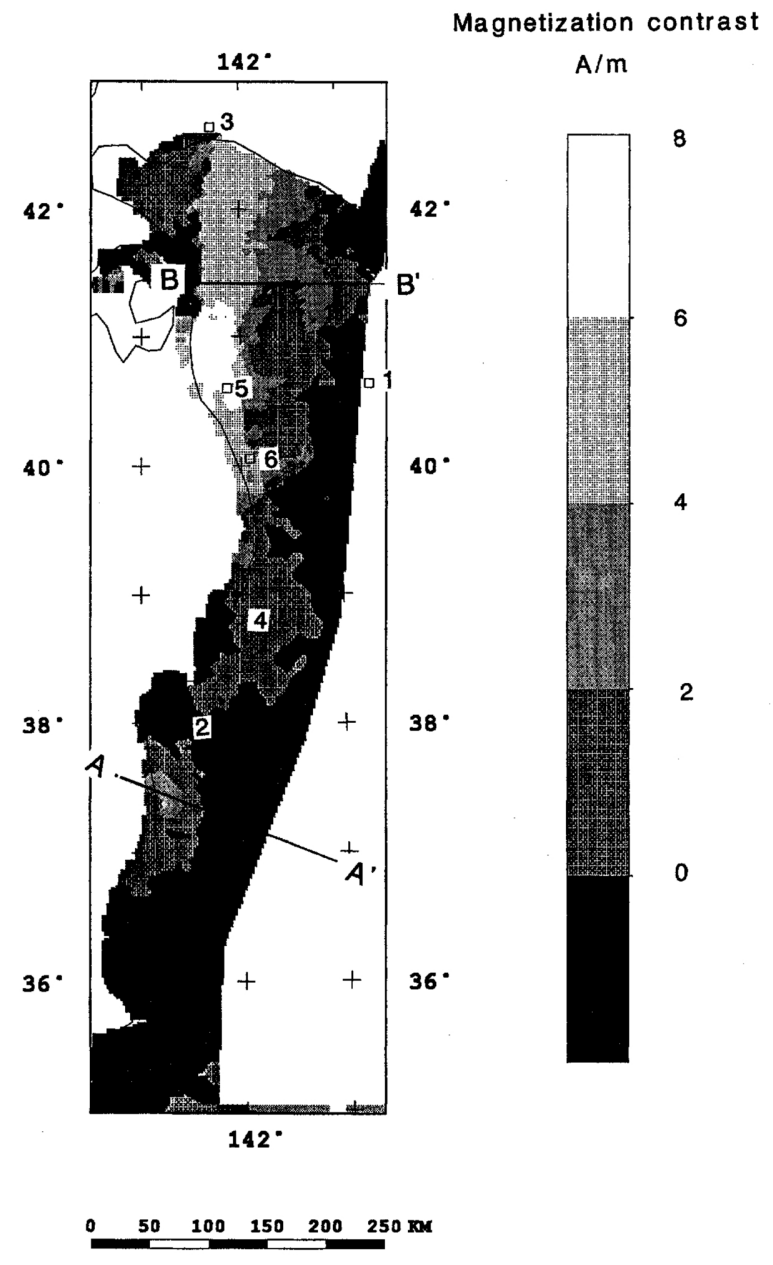

Fig. 9. Gray-scale pseudo-magnetization map. Squares with numbers mark the location of drill holes. Lines A-A' and B-B' show locations of modeled gravity profiles.

Comparison of the model B-B' (Fig. 8) with the pseudo-magnetization map (Fig. 9) gives puzzling results. Both models of $\mathrm{B}-\mathrm{B}^{\prime}$ put the top of the western pluton at a depth of about $5 \mathrm{~km}$ and the bottom at $15 \mathrm{~km}$ and yield magnetizations of $3.8 \mathrm{~A} / \mathrm{m}$ (Fig. 8(a)) and $2.74 \mathrm{~A} / \mathrm{m}$ (Fig. 8(b)). The pseudomagnetization map, created from a $14 \mathrm{~km}$ thick model with the top of the source at $1 \mathrm{~km}$ depth shows higher magnetizations that range from 4 to $6 \mathrm{~A} / \mathrm{m}$ (Fig. 9). The reason for higher magnetizations is not clear. The $60-\mathrm{km}$ width and position of the 4 to $6 \mathrm{~A} / \mathrm{m}$ zone (Fig. 9) matches the relatively shallow parts of the western pluton in B-B' (Fig. 8).

Areas south of $40^{\circ} \mathrm{N}$ do not show the same high values of magnetization $(>4 \mathrm{~A} / \mathrm{m})$ as to the north. Drill hole 4 and on-land drill holes between 37 and $38^{\circ} \mathrm{N}$ latitude (Abe and Ishihara, 1985; Yanagisawa et al., 1989) encounter Kitakami plutons at depths less than $1.8 \mathrm{~km}$, but no volcanic rocks. The Kitakami volcanic rocks crop out near the Hatagawa Fault (Figs. 2 and 7) but are only sparsely distributed (Yamamoto et al., 1989). Modeling of the magnetic data along profile A-A' (Fig. 7), which crossed the area of highest values on the pseudo-magnetization map in the south (Fig. 9), obtained reasonable susceptibilities for the pluton without volcanic rocks. The drill hole data and modeling suggest that the 
Kitakami plutons south of $40^{\circ} \mathrm{N}$ are probably even shallower than those to the north. Despite this, the average magnetizations are higher to the north. The above information implies that the Kitakami andesites are not present or very thin south of $40^{\circ} \mathrm{N}$ latitude.

The Kitakami pluton modeled along profile $\mathrm{A}-\mathrm{A}^{\prime}$ (Fig. 7) has a single magnetization with a varying top depth. It may have been possible to fit the magnetic data with variably magnetized bodies to represent the pluton. Modeling of aeromagnetic data in the Kitakami mountains showed that a single calculated magnetization could describe each pluton and correspond to the average measured value for that pluton (Ogawa, 1992). Measured susceptibilities typically vary less than a factor of two within individual exposed Kitakami plutons (Kanaya, 1974; Ishihara, 1979). The geometry of the model along profile A$\mathrm{A}^{\prime}$ were partially constrained by gravity, bathymetry, and seismic data. Comparison of the Kitakami pluton model (Fig. 7) with the pseudo-magnetization map (Fig. 9) suggests that the magnetization variations along $\mathrm{A}-\mathrm{A}^{\prime}$ (Fig. 9) may not be real and reflect depth variations to the top of the Kitakami pluton. The area along $\mathrm{A}-\mathrm{A}^{\prime}$ on the pseudo-magnetization map (Fig. 9) with magnetizations in the 2 to $4 \mathrm{~A} / \mathrm{m}$ range corresponds to the modeled shallow parts of the pluton offshore (between the coast and distance 55, Fig. 7). The eastern edge of the $0-2 \mathrm{~A} / \mathrm{m}$ area (Fig. 9) coincides with the eastern edge of the pluton modeled along $\mathrm{A}-\mathrm{A}^{\prime}$ (distance 90, Fig. 7).

The magnetic data are not very sensitive to the thickness of the plutons. Onshore, 3-km thick plutons and $15-\mathrm{km}$ thick plutons with similar average magnetizations can be associated with aeromagnetic anomalies of nearly equal amplitude (Ogawa, 1992). Therefore, Fig. 9 does not show thickness variations but differences in magnetization and depth to the top of the source. Areas showing magnetizations greater than $4 \mathrm{~A} / \mathrm{m}$ are probably underlain by andesites and plutons. Other areas of positive magnetization may only be underlain by plutons.

Previous studies (Ogawa and Suyama, 1975; Okubo et al., 1991; Makino et al., 1992) suggested that the Kitakami plutons are only present on land. The pseudo-magnetization map (Fig. 9) clearly outlines the maximum extent of the plutons and andesites and show that these rocks extend at least $150 \mathrm{~km}$ further east than previously thought. If some of the high magnetization values on the east side of the map are caused by serpentines then the eastern edges of the Kitakami plutons are about $100 \mathrm{~km}$ further east than previously thought.

\subsection{Density mapping}

In order to create a realistic density contrast map from the free-air gravity data (Fig. 6) I analytically downward continued and draped the data (Cordell and Grauch, 1985) onto the top of the bathymetry (Fig. 10). This process minimizes the problem of creating negative gravity anomalies due to increases in depth to source. The draped data were "terraced" and the output multiplied by a constant to yield a reasonable range of density contrast values. This density contrast grid was input to a forward computer program (Blakely, 1981) for calculating the gravity effect of a given geometry and density. The bathymetry (Fig. 10) described the top of the body. The bottom was mostly flat, at depth of $15 \mathrm{~km}$ except on the east side where it was described by the subducting Pacific plate to a depth of $15 \mathrm{~km}$. I chose a $15 \mathrm{~km}$ depth because most of the known density variation occurs above this (Figs. 7 and 8) densities of the lower crust and mantle are poorly constrained. The calculated gravity anomaly from this model was multiplied by a scaling constant to match the observed data. I multiplied the input density contrast grid by the scaling constant to obtain a density contrast map that best describes the upper $15 \mathrm{~km}$ offshore area (Fig. 11).

Areas of negative density contrast between -100 and $-400 \mathrm{~kg} / \mathrm{m}^{3}$ are associated with the trench and Hidaka Basin (Fig. 11) and reflect the low density sedimentary rocks within them as well as increases in depth to these rocks.

The highest positive density contrasts, between 200 and $300 \mathrm{~kg} / \mathrm{m}^{3}$, are near-shore. In the north, the high density contrasts correspond to the interpreted pre-Cretaceous Kitakami basement rocks $(2740 \mathrm{~kg}$ ) $\mathrm{m}^{3}$, Fig. 8). In the south, comparison of the density contrast map along profile A-A' (Fig. 11) and the model (Fig. 7) shows that the near-shore area of 200 and $300 \mathrm{~kg} / \mathrm{m}^{3}$ density contrast is caused primarily by the density contrast between sedimentary rocks, that is, the contrast between the $2600 \mathrm{~kg} / \mathrm{m}^{3}$ and $2100 \mathrm{~kg} / \mathrm{m}^{3}$ 


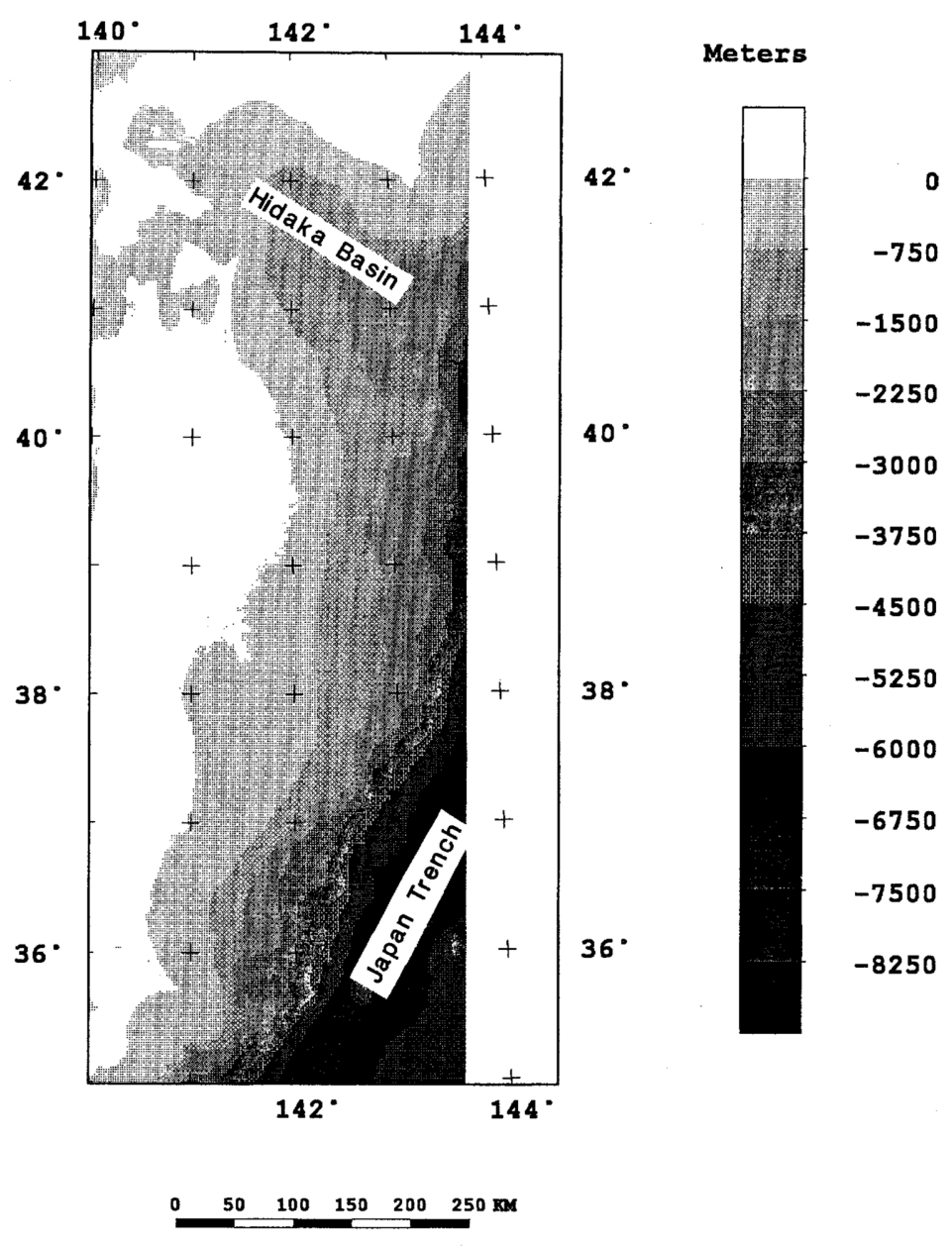

Fig. 10. Gray-scale bathymetry map.

layer in model A-A' (Fig. 7). Profile A-A' crosses a second area to the east of 200 and $300 \mathrm{~kg} / \mathrm{m}^{3} \mathrm{density}$ contrast (Fig. 11). This also seems to be related to the contrast between sedimentary rocks; the contrast between the modeled $2740 \mathrm{~kg} / \mathrm{m}^{3}$ body and adjacent 2540 and $2600 \mathrm{~kg} / \mathrm{m}^{3}$ bodies (Fig. 7).

The Kitakami plutons delineated by the magnetic data have nearly the same density as surrounding sediments (Figs. 7 and 8 ) and do not seem to be reflected in the density map, except perhaps at the coast.

\section{Summary}

Correlation of positive marine magnetic anomalies, on land geology, drill hole data, and 2-1/2dimensional models show that Kitakami plutons and possibly their associated volcanic rocks compose part of the modern forearc basement and lie 100-150 km further east than previously thought (Ogawa and Suyama, 1975; Okubo et al., 1991; Makino et al., 1992). A method to create magnetization and density contrast maps was employed to produce a three-dimensional picture of the forearc basement rock properties averaged over a 14-km thickness. Comparisons of the magnetization map with drill information suggest that the Cretaceous andesites may contribute to the observed positive aeromagnetic anomalies and 


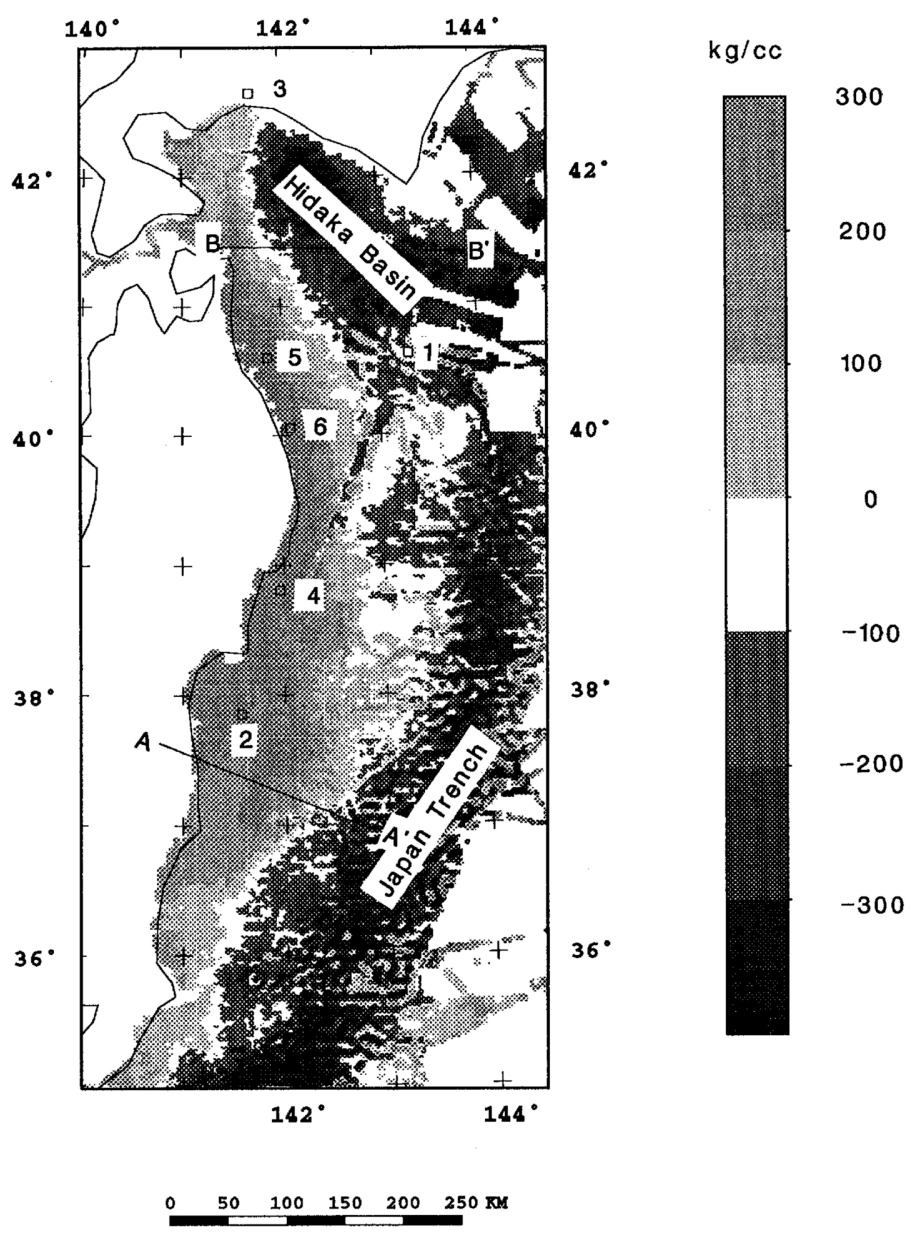

Fig. 11. Gray-scale density contrast map. Squares with numbers mark the location of drill holes. Lines A-A' and B-B' show locations of modeled gravity profiles.

therefore may be more magnetic than the sparse on-land rock property measurements suggest. The lower magnetization values for the area south of $40^{\circ} \mathrm{N}$ latitude than for the area to the north may indicate that the andesites are not present in the south and the depth of erosion was greater there. Widths and positions of high magnetization zones mapped by the terrace method are interpreted to be due to buried plutons and match the widths and positions of the plutons modeled with a 2-1/2-dimensional program.

The gravity data primarily reflect density variations within the marine sedimentary rocks, and do not seem to delineate the plutons, a rather surprising result. The 2-1/2-dimensional models and comparison of the gravity and magnetic and density and magnetization data do not correlate, confirmation that the gravity and magnetic anomalies have different sources.

I thank Dr. Masahiko Makino for providing the magnetic data and Dr. Takemi Ishihara for providing the gravity data. This work was supported by the Japanese Science and Technology Agency and Agency of Industrial Science and Technology Fellowships, and the U.S. Geological Survey's Geothermal Program. 


\section{REFERENCES}

Abe, T. and S. Ishihara, Chemical composition of tonalites from Matsukawaura, northeastern Abukuma Highland, Geol. Surv. Japan Bull., 36, 167-171, 1985.

Asano, S., N. Den, H. Hotta, T. Yoshii, Y. Ichinose, N. Sakajiri, and T. Sasatani, Seismic refraction and reflection measurements around Hokkaido Part 2. Crustal structure of the continental slope off Hidaka, J. Phys. Earth, 27, 497-509, 1979.

Baranov, V., A new method for interpretation of aeromagnetic maps: pseudo-gravimetric anomalies, Geophys., 22, 359-383, 1957.

Bath, G. D., Aeromagnetic anomalies related to remanent magnetism in volcanic rock, Nevada Test Site, Geol. Soc. Amer. Mem., 110, 135-146, 1968.

Blakely, R. J., A program for rapidly computing the magnetic anomaly over digital topography, U.S. Geol. Surv. Open File Rep., $81-298$, p. 45,1981

Committee for Co-Ordination of Joint Prospecting for Mineral Resources in Asian Offshore Areas (CCOP), T. B., Total Sedimentary Isopach Maps Offshore East Asia, edited by J. Hirayama, pp. 39-41, 1991.

Cordell, L. and V. J. S. Grauch, Mapping basement magnetization zones from aeromagnetic data in the San Juan basin, New Mexico, in The Utility of Regional Gravity and Magnetic Anomaly Maps, edited by W. Hinze, pp. 181-197, Society of Exploration Geophysicists, Tulsa, OK, 1985.

Cordell, L. and A. E. McCafferty, A terracing operator for physical property mapping with potential field data, Geophys., 54, 621$634,1989$.

Cordell, L., J. D. Phillips, and R. H. Godson, U.S. Geological Survey potential fields geophysical software, version 2.0, U.S. Geological Survey Open File Report, 92-18a-g, 6 diskettes, 1992.

Couch, R. W. and R. P. Riddihough, The crustal structure of the western continental margin of North America, in Geophysical Framework of the Continental United States, edited by L. C. Pakiser and W. D. Mooney, pp. 103-128, Geological Society of America Memoir, Boulder, CO, 1989.

Couch, R. W. and S. Woodcock, Gravity and structure of the Continental margins of southwestern Mexico and northwestern Guatemala, J. Geophys. Res., 86, 1829-1940, 1981.

Dubois, R. L., Remanent, induced, and total magnetism of a suite of serpentine specimens from the Sierra Nevada, California, J. Geophys. Res., 68, 267-278, 1963.

Finn, C., Structure of the Washington convergent margin, implications for other subduction zones and for continental growth process, Ph.D., University of Colorado, 1988.

Finn, C., Geophysical constraints on Washington convergent margin structure, J. Geophys. Res., 95, 19,533-19,546, 1990.

Finn, C., Aeromagnetic evidence for Kitakami granitoids offshore: Tectonic implications for the evolution of northeastern Honshu (abs.), in Muroto International Conference on Accretionary Prisms, Nankai Trough, Shimanto Belt and Global Comparisons, 30, Ocean Research Institute, University of Tokyo, Shikoku, Japan, 1991.

Finn, C., Aeromagnetic evidence for a buried Early Cretaceous magmatic arc, northeast Japan, J. Geophys. Res. (in press).

Fujii, S. and T. Moriya, Upper crustal structure in the Hidaka district by refraction measurements using the quarry blasts, Geophys. Bull. Hokkaido Univ., Sapporo, Japan, 42, 169-190, 1983.

Fukao, Y., S. Yamamoto, and M. Kono, Gravity anomaly across the Peruvian Andes, J. Geophys. Res., 94, 3867-3890, 1989.

Geological Survey Institute, Magnetic Charts for the Epoch 1980.0, Geol. Surv. Inst. Bull., XXVIII, 106-108, 1983.

Grow, J., Crustal and mantle structure of the central Aleutian arch, G. S. A. Bull., 84, 2169-2192, 1973.

Grow, J. and C. Bowin, Evidence for high density crust and mantle beneath the Chile trench due to the descending lithosphere, J. Geophys. Res., 80, 1449-1458, 1975.

Hayes, D. E. and S. D. Lewis, A geophysical study of the Manila Trench, Luzon, Philippines, J. Geophys. Res., 89, 9171-9195, 1984.

Hildenbrand, T. H., FFTFIL: A filtering program based on two-dimensional Fourier analysis, U.S. Geological Survey Open-File Report, 83-237, 1983.

Honza, E., Pre-site survey of the Japan trench transect, deep sea drilling project, in Scientific Party Legs 56 and 57, Initial Reports of the Deep Sea Drilling Project, edited by U.S. Government Printing Office, Washington, D.C., 1980.

Honza, E., K. Tamaki, and F. Murakami, Geological map of the Japan and Kurile trenches and the adjacent areas, Geolog. Surv. Japan Mar. Geol. Map Ser., 11, 1978.

Ishihara, S., Metallogenesis in the Japanese island-arc system, J. Geol. Soc. London, 135, pt. 4, 389-406, 1978.

Ishihara, S., Lateral variation of magnetic magnetization of the Japanese granitoids, J. Geol. Soc. Japan, 85, 509-523, 1979.

Iwasaki, T., T. Yoshii, A. Ikami, T. Iidaka, T. Moriya, T. Masuda, M. Nishiwaki, A. Kobayashi, and T. Tsutsui, Crustal structure in the Kitakami region deduced from seismic refraction experiment; Kuji-Ishinomaki profile (abs.), Program of Abstracts of the Seismological Society of Japan, 212, 1991.

Japan Association of Natural Gas, Recent Oil Exploration in Japan, Tokyo, Japan, 1986.

Jolivet, L., J. P. Cadet, and F. Lalevee, Mesozoic evolution of northeast Asia and the collision of the Okhotsk microcontinent, Tectonophysics, 149, 89-109, 1988.

Kanaya, H., Potassium, thorium, uranium, and magnetic susceptibility, in Cretaceous granitic rocks in the Kitakami Mountains, petrography and zonal arrangement, Geological Survey of Japan Report, pp. 91-120, 1974.

Kanisawa, S., T. Yoshida, K. Ishikawa, and K. Aoki, Geochemistry of the Cretaceous plutonic rocks, Kitakami Mountains, Res. 
Reps. Lab. Nucl. Sci. Tohoku Univ., 19, 251-264, 1984.

Kimura, G., S. Miyashita, and S. Miyasaka, Collision tectonics in Hokkaido and Sakhalin, in Accretion Tectonics in CircumPacific Regions, edited by M. Hashimoto and S. Uyeda, pp. 107-122, Terra Scientific Publishing Co., Tokyo, Japan, 1983.

Kubo, K. and T. Yamamoto, Cretaceous intrusive rocks of the Haramachi district, eastern margin of the Abukuma Mountainspetrography and K-Ar age, J. Geol. Soc. Japan, 96, 731-743, 1990.

Kubo, K., Y. Yanagisawa, T. Yoshioka, T. Yamamoto, and F. Takizawa, Geology of the Haramachi and Omika district, with geologic sheet map at 1:50,000, Geological Survey of Japan, 1990.

Maeda, J., Opening of the Kuril Basin deduced from the magmatic history of central Hokkaido, north Japan, Tectonophysics, 174, 235-255, 1986.

Makino, M. and Y. Okubo, Spectral analysis of marine magnetic anomalies, Geophys. Expl., 41, 372-381, 1988.

Makino, M., Y. Okubo, and T. Nakatsuka, Magnetic map of the Japanese Islands, 1:200,000 scale map series 23, Geological Survey of Japan, 1992.

Murata, Y., Y. Suda, and T. Kikuchi, Rock physical properties of Japan-Density, magnetism, P-wave velocity, porosity, and thermal conductivity, Geol. Surv. of Japan Report, No. 276, 303 p., 1991 (in Japanese with English abstract).

Nafe, J. E. and C. L. Drake, Variation with depth in shallow and deep water marine sedimentary rocks of porosity, density and the velocities of compressional and shear waves, Geophys., 22, 523-552, 1957.

Niida, K. and N. Kito, Cretaceous arc-trench systems in Hokkaido, Assoc. Geol. Collab. Japan Monog., 31, 379-402, 1986.

Niitsuma, N., Y. Saito, and A. Taira, Reconstruction of the Japanese Islands before the Japan Sea Opening, J. Phys. Earth, 36, S133-S142, 1988.

Nishimura, K. and F. Murakami, Gravity measurement, in Geological Investigation of the South Kurile Trench and Slope Areas, GH-76-2 Cruise, April-June, 1976, pp. 21-42, Geological Survey of Japan, 1977.

Nishimura, K., F. Murakami, and M. Tanahashi, Gravity and geomagnetic surveys on the southeastern offshore of the Boso Peninsula, April-June, 1980 (GH-80-2 and -3 cruises), in Geological Investigation of the Junction Area of the Tohoku and Ogasawara Arcs, pp. 34-46, Geological Survey of Japan, 1984.

Ogawa, K. and J. Suyama, Distribution of aeromagnetic anomalies, Hokkaido, Japan and its geologic implications, in Volcanoes and Tectonosphere, edited by H. Aoki and S. Iizuka, Tokai University Press, Tokai, Japan, 1975.

Ogawa, Y., Deep crustal resistivity structure revealed by wideband magnetotellurics Tohoku and Hokkaido region, Ph.D. Dissertation, 320 pp., Univ. of Tokyo, 1992.

Okubo, Y., M. Makino, and S. Kasuga, Magnetic model of the subduction zone in the northeast Japan Arc, Tectonophysics, 192, 103-115, 1991.

Otofuji, Y., T. Matsuda, and S. Nohda, Paleomagnetic evidences for the Miocene counter clockwise rotation of northeast Japanrifting process of the Japan arc, Earth Planet. Sci. Lett., 75, 265-277, 1985.

Saito, Y. and M. Hashimoto, South Kitakami region: An allochthonous terrane in Japan, J. Geophys. Res., 87, 3691-3696, 1982.

Sakurai, M., A. Mogi, J. Chujo, and T. Miyazaki, Multichannel seismic reflection profiling off Joban District Northeast-Japan, Rep. Hydro. Res., 16, 1-20, 1981.

Segawa, J. and T. Furuta, Geophysical study of the mafic belts along the margins of the Japanese islands, Tectonophysics, 44, $1-26,1978$

Segawa, J. and S. Oshima, Buried Mesozoic volcanic-plutonic fronts of the north-western Pacific island arcs and their tectonic implications, Nature, 256, 15-19, 1975.

Segawa, J. and Y. Tomoda, Gravity measurements near Japan and study of the upper mantle beneath the oceanic trench-Marginal sea transitional zones, in The Geophysics of the Pacific Ocean Basin and Its Margin, edited by G. H. Sutton, M. H. Manghnani, and R. Moberly, pp. 35-52, American Geophysical Union, Washington, D.C., 1976.

Suyehiro, K., H. Inatani, T. Kono, and K. Yamamoto, Upper crustal structure beneath the continental slope off the Joban Coast, Honshu, Japan, J. Phys. Earth, 32, 83-96, 1984.

Suyehiro, K., Y. Kaiho, A. Nishizawa, T. Kanazawa, and H. Shimamura, Seismic upper crust of the Japan Trench inner slope, Tohoku Geophys. J., 33, 281-305, 1990.

Taira, A., S. Saito, and M. Hashimoto, The role of oblique subduction and strikeslip tectonics in the evolution of Japan, in Geodynamics of the Western Pacific-Indonesian Region, edited by T. W. C. Hilde and S. Uyeda, pp. 303-316, American Geophysical Union Geodynamics Series, Vol. 11, Washington, D.C., 1983.

Tanaka, S. and H. Kanaya, Rock densities in the Kitakami Mountains Part I, Geol. Surv. Japan Bull., 37, 471-477, 1986.

Tanaka, S. and H. Kanaya, Rock densities in the Kitakami Mountains Part II, Geol. Surv. Japan Bull., 38, 191-196, 1987.

Vening Meinesz, F. S., Gravity Expeditions at Sea, Netherlands Geodetic Committee, Waltman, Delft, 1934.

von Huene, R., M. Langseth, N. Nasu, and H. Okada, A summary of Cenozoic tectonic history along the IPOD Japan trench transect, G. S. A. Bull., 93, 829-846, 1982.

Watts, A. B. and M. Talwani, Gravity effects of downgoing lithospheric slabs beneath island arcs, G. S. A. Bull., 86, 1-4, 1975.

Webring, M. W., SAKI: A FORTRAN program for generalized linear inversion of gravity and magnetic profiles, U.S. Geol. Surv. Open File Rep., 75-648, 104 pp., 1985.

Yamada, N., Y. Teraoka, and M. Hata, Geological map of Japan, scale 1:1,000,000, in Geological Atlas of Japan, pp. 3-19; 2225, Geological Survey of Japan, 1982.

Yamada, N., E. Saito, and Y. Murata, Computer-generated geologic map of Japan, 1:2,000,000, Map series, No. 22, Geological 
Survey of Japan, 1990.

Yamamoto, T., K. Kubo, and F. Takizawa, Early Cretaceous volcanic rocks in the eastern margin of the Abukuma Mountains: lithostratigraphy and eruptive age of the Takanokura Formation in the Haramachi area, Northeast Japan, J. Geol. Soc. Japan, 95, 701-710, 1989.

Yanagisawa, Y., K. Nakamura, Y. Suzuki, K. Sawamura, F. Yoshida, Y. Tanaka, Y. Honda, and M. Tanahashi, Tertiary biostratigraphy and subsurface geology of the Futaba district, Joban Coalfield, northeast Japan, Geol. Surv. Japan Bull., 40, $405-467,1989$.

Yufutsu Research Group of JAPEX Sapporo, S. Okamura, T. Katoh, K. Shibata, Y. Ganzawa, and S. Uchiumi, Cretaceous granitoids from the well at the eastern area of Tomakomai, Hokkaido, J. Geol. Soc. Japan, 98, 547-550, 1992. 